
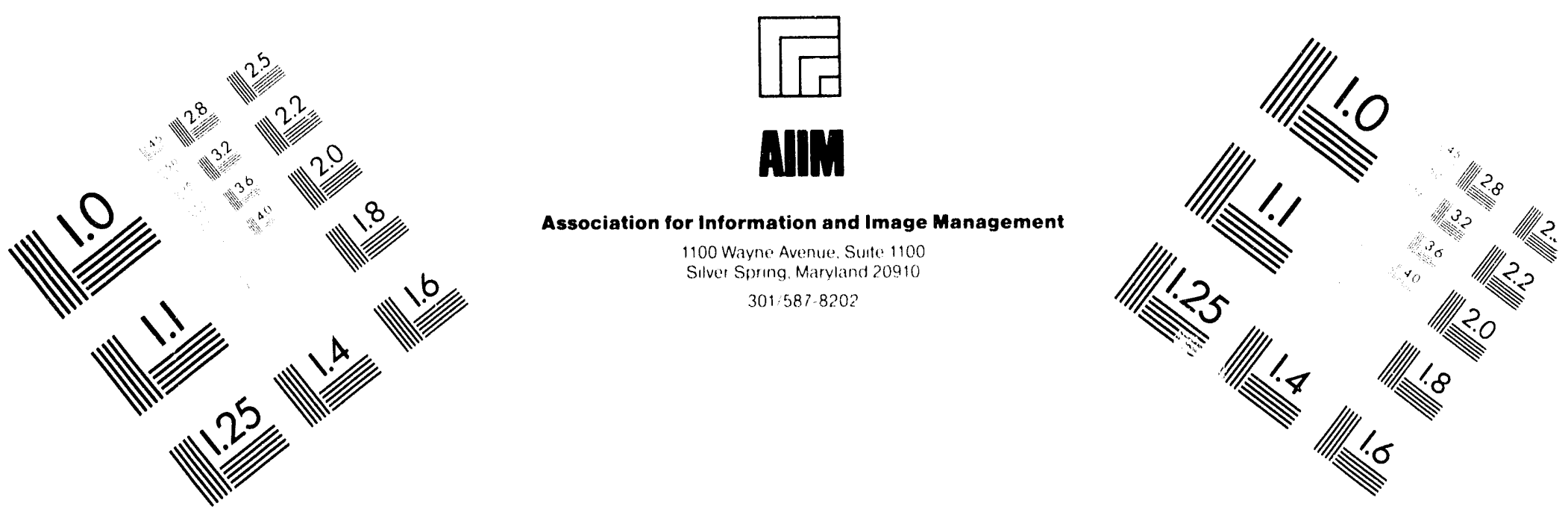

\title{
Centimeter
}

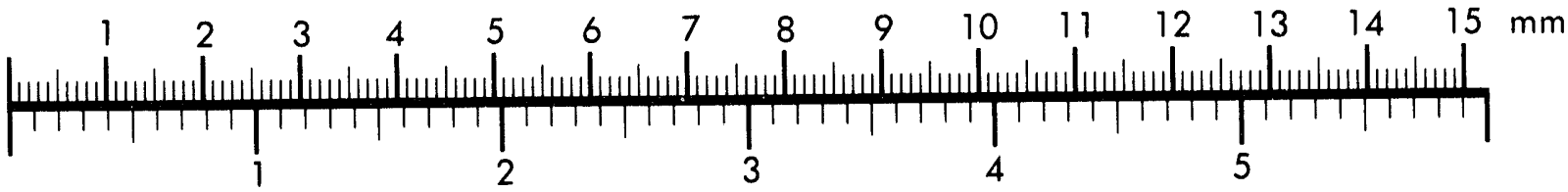
Inches
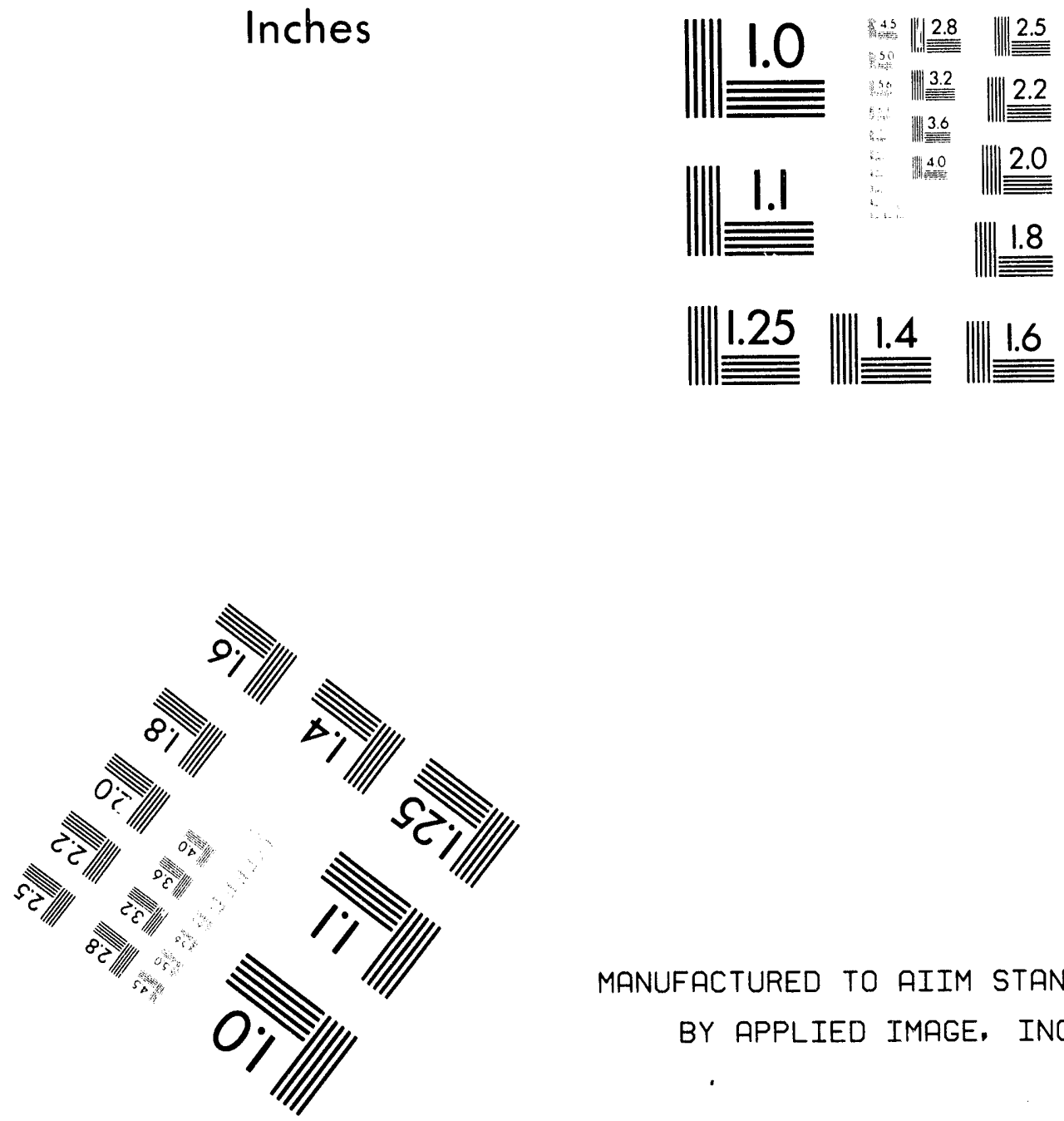

MANUFACTURED TO AIIM STANDARDS

BY APPLIED IMAGE, INC.

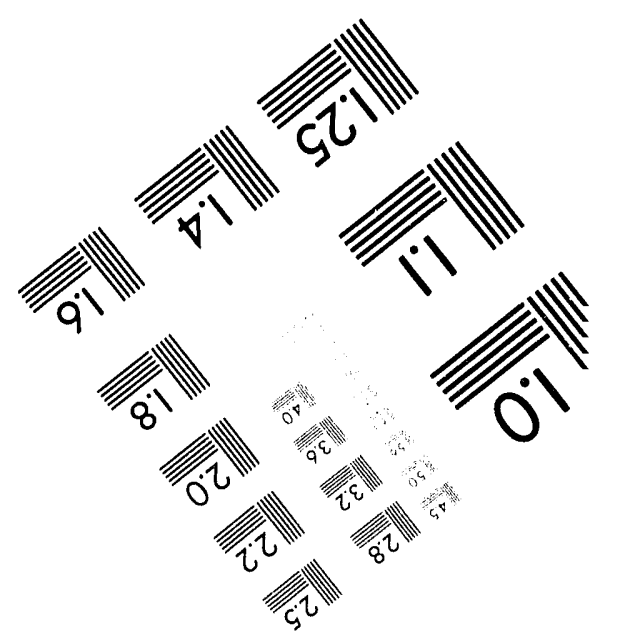



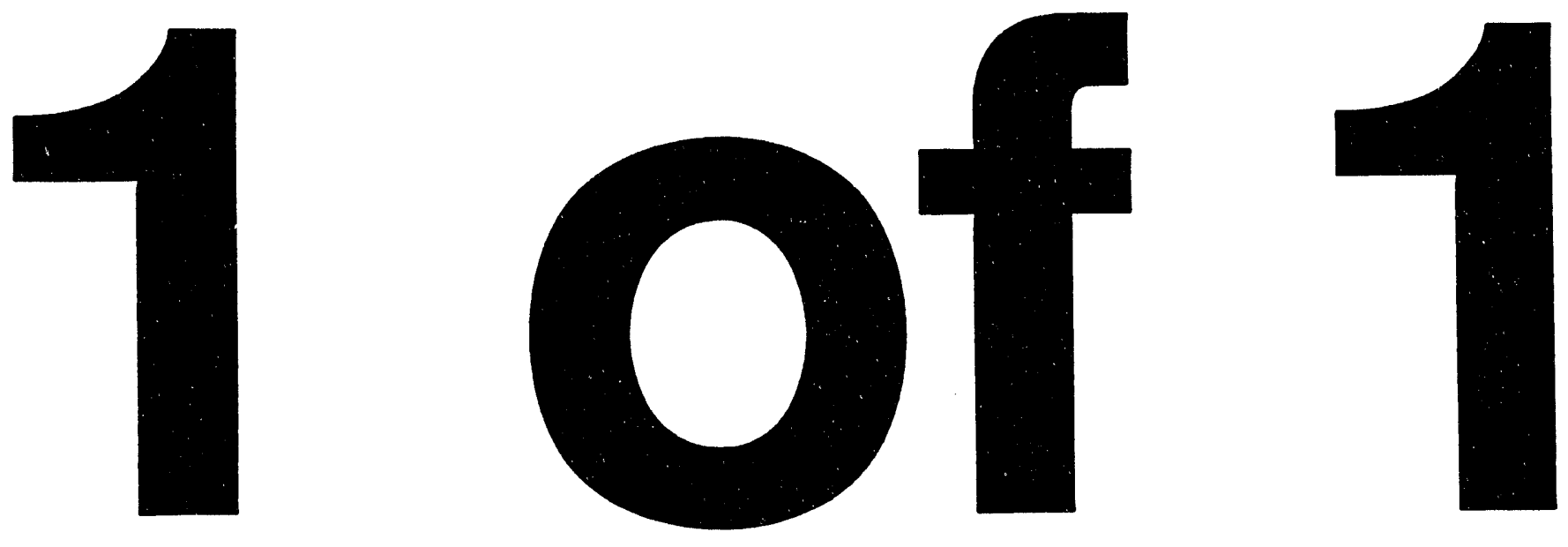


\section{RESRAD SOIL CONCENTRATION GUIDELINES FOR THE OLD F-AREA RETENTION BASIN}

by

Hamby, D. M.

Westinghouse Savannah River Company

Savannah River Site

Aiken, South Carolina 29808

DOE Contract No. DE-AC09-89SR18035

This paper was prepared in connection with work done under the above contract number with the U. S. Department of Energy. By acceptance of this paper, the publisher and/or recipient acknowledges the U. S. Government's right to retain a nonexclusive, royalty-free license in and to any copyright covering this paper, along with the right to reproduce and to authorize others to reproduce all or part of the copyrighted paper. 


\section{DISCLAIMER}

This report was prepared as an account of work sponsored by an agency of the United States Government. Neither the United States Government nor any agency thereof, nor any of their employees, makes any warranty, express or implied, or assumes any legal liability or responsibility for the accuracy, completeness, or usefulness of any information, apparatus, product, or process disclosed, or represents that its use would not infringe privately owacd rights. Reference herein to any specific commercial product, process, or service by trade name. trademark. manufacturer, or otherwise does not necessarily constitute or imply its endorsemeat, recommendation, or favoring by the United States Government or any agency thereof. The views and opinions of authors expressed berein do nor necessarily state or reflect those of the United States Government or any agency thereof.

This report has been reproduced directly from the best available copy.

Available to DOE and DOE contractors from the Office of Scieatific and Technical Information. P. O. Box 62, Oak Ridge. TN 37831; prices available from (615) $576-8401$.

Available to the public from the National Technical Information Service, U. S. Deparmeat of Commerce, S285 Port Royal Rd., Spriaffield. VA 22161 
RESRAD SOIL CONCENTRATION GUIDELINES FOR THE OLD F-AREA RETENTION BASIN

D.M. Hamby

February 24, 1994

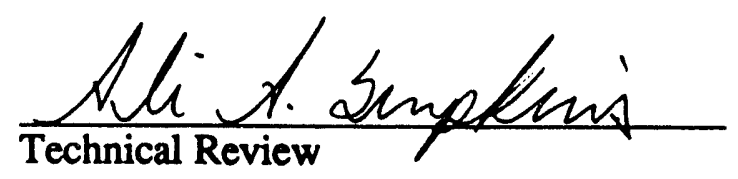

Westinghouse Savannah River Company Savannah River Site Aiken, SC 29808 


\section{RESRAD SOIL CONCENTRATION GUIDELINES \\ FOR THE OLD F-AREA RETENTION BASIN}

D.M. Hamby

\section{SUMMARY}

Concentration guidelines for residual radionuclides in soil at the site of the Old F-Area Retention Basin (281-3F) have been calculated using a dose-based approach. Estimation of these soil guidelines was completed using RESRAD 5.0 in accordance with the DOE RESRAD methodology specified in DOE/CH/8901 (Gi89). Guidelines are provided for the two predominant nuclides, Sr-90 and Cs-137, known to be present in the soil beneath the old basin (Sc87). A guideline is also given for Pu-238 since it is known to exist at the H-Area Retention Basin (281-3H). Site-specific soil characteristics are defined for the areas above, within, and beneath the contaminated zone.

\section{INTRODUCTION}

A soil concentration guideline is defined as a radionuclide concentration in soil that is acceptable if a site is to be used without radiological restriction. Generic guidelines for thorium and radium in soil, airborne radon decay products, external gamma radiation, surface contamination, and residual radionuclides in air and water are specified in DOE Order 5400.5 and other guidance. Soil guidelines for other radionuclides must be derived on a site-specific basis using RESRAD, the DOE residual radioactive material code (Gi89). Soil concentration guidelines have been calculated for 1000 years into the future. The lowest, most restrictive guideline calculated for this period is taken as the current soil guideline.

To derive site-specific soil guidelines, a basic radiation dose limit of $100 \mathrm{mrem} / \mathrm{yr}$, as specified by DOE, is normally applied to a member of the critical population group. The radiation dose limit is based on radiation protection standards and requirements specified in DOE Order 5400.5. However, since the drinking water pathway is expected to dominate the dose and since the State of South Carolina and the EPA National Primary Drinking Water Regulations (40CFR141.16) requires the drinking water radiological dose to be less than the drinking water standard of $4 \mathrm{mrem} / \mathrm{yr}$, the guidelines generated in 
this report will be based on a dose limit equal to the drinking water standard. It is assumed, for the purpose of deriving soil guidelines, that the critical population group is a family that establishes residence on a site that has been released for use without radiological restrictions. The controlling principles for all guidelines are (1) the annual radiation dose received by a member of the critical population group from the residual radioactive material -- predicted by a realistic but conservative analysis and averaged over a time interval of 50 years -- should not exceed the basic dose limit and (2) doses should be kept as low as reasonably achievable (Gi89). Other exposure scenarios are less conservative and evaluation is not necessary for the determination of soil concentration guidelines.

\section{DESCRIPTION OF RESRAD}

Models for deriving soil concentration guidelines from dose limits are simplified representations of complex processes. It is not feasible to obtain sufficient data to fully or accurately characterize transport and exposure processes. Similarly, it is not possible to predict future conditions with certainty. Hence, there will be uncertainties in the guideline values presented here. The models incorporated into RESRAD are very conservative, and the calculated doses corresponding to soil guideline values of the radionuclide concentrations are expected to be conservative estimates (overestimates) of the actual doses.

The most conservative exposure scenario (future resident farmer) is considered for the estimation of soil concentration guidelines. The resident farmer has no access restrictions and is assumed to be exposed to radioactive contaminants through the eight exposure pathways discussed below: 1) external ground-shine, 2) inhalation of resuspended dust, 3) ingestion of plant food, 4) ingestion of meat, 5) ingestion of milk, 6) ingestion of fish, 7) ingestion of groundwater, and 8) incidental ingestion of soil. Radon exposure was not considered when calculating these soil guidelines. The information in this section that follows is condensed from Gilbert et al. (1989).

External Radiation. Gamma radiation from radionuclides distributed throughout the contaminated zone is the dominant external radiation pathway and the only external pathway taken into account when calculating soil guidelines. The dose due to external gamma radiation is first calculated for an individual exposed continuously to radiation from an infinite contaminated zone at a distance of one meter from the ground surface. 
Correction factors are then applied for the finite area and thickness of the contaminated zone, shielding by a cover of contaminated soil, irregular shape, shielding by the floors and walls of a house, and less-than-continuous occupancy.

Inhalation. Inhalation exposure results primarily from inhalation of contaminated dust. Modeling the airborne exposure pathway segment consists of two steps: (1) modeling the process by which radionuclides become airborne and (2) modeling the process by which the airborne radionuclides are transported to a human exposure location and diluted before inhalation. The first step gives the ratio of the concentration in air near the source before it is dispersed and diluted to the concentration in the resuspended layer of dust; the second step gives the ratio of the airborne concentration at the point of exposure to the undiluted airborne concentration at the source.

Food Ingestion. Four food pathway categories are taken into account: plant foods, meat, milk, and aquatic foods. The food pathways are activated by scenarios in which crops are grown in or close to the contaminated zone. Plant crops grown in the contaminated zone will be the dominant and most frequent contributor, especially if the crops are irrigated with contaminated water. Contributors from the meat and milk pathways, which involve an additional pathway segment for transfer of radionuclides from fodder or water to the meat or milk, will generally be smaller but not insignificant. Vegetable gardens are common in urban and suburban areas as well as rural areas, whereas raising livestock is generally limited to rural areas. The aquatic food pathway should be considered only in areas where the topography and soil characteristics are favorable for building a pond.

Radionuclide transport through the food pathways is determined by the quantities of different foods consumed (dietary factors) and the fraction of the diet from foods that are contaminated by radionuclides from the contaminated zone (which is determined by the fraction raised locally and the area of the contaminated zone). Also important in radionuclide transport is the cover depth and contaminated zone thickness relative to the root zone of the plants, the various transfer factors from root or foliage to plants and from fodder or water to meat or milk, and the concentrations of radionuclides in water that has percolated down through the contaminated zone.

Water Pathway Segments. A water pathway segment connects the contaminated zone with a point of water withdrawal for drinking or irrigation or with a pond where aquatic foods are raised for human consumption (see Figure 1). It is characterized by a water/soil 
concentration ratio for each radionuclide, defined as the ratio of the radionuclide concentration in the water at the point of withdrawal to the radionuclide concentration in the contaminated zone. Irrigation and drinking water are assumed to be taken from a pond and well, respectively. The well is assumed to be at the down-gradient edge of the contaminated zone. The pond water is contaminated by water that seeps to the surface after percolating down through the contaminated zone. Natural precipitation or irrigation water infiltrates the contaminated zone and transports radionuclides through the vadose zone and the aquifer to a well or point of seepage into surface water.

The groundwater pathway models implemented in RESRAD apply only to situations for which the hydrological strata can reasonably be approximated by a sequence of uniform, horizontal strata. For sites having more complicated strata such as fracture zones, simple models may be used to provide reasonable estimates if a set of effective hydrogeologic flow parameters is used. The accuracy of the results is determined by the accuracy of the input parameters.

The surface water is assumed to be a pond with an inflow dilution factor equal to the ratio of the annual volume of water that infiltrates the contaminated zone to the annual total inflow of water into the pond. Transport times from the contaminated zone to the pond are assumed to be the same as for the onsite well; no credit is taken for the additional time for radionuclides to be transported from the edge of the contaminated zone to the point of seepage. This simplified model will give a conservative estimate of the water/soil concentration ratio for a pond. The concentration factor that characterizes the drinking water pathway is obtained by multiplying the water/soil concentration ratio by the annual quantity of contaminated drinking water consumed by an individual.

\section{CONTAMINATED AREA CONCEPTUAL MODEL}

The contaminated zone is assumed to have lateral dimensions equal to the dimensions of the original retention basin $(61 \mathrm{~m} \times 37 \mathrm{~m})$. Based on previous excavation and soil sampling (Sc87), it was determined that the contaminated zone is approximately 2 meters deep with a cover soil thickness of 2.7 meters. The contamination is assumed to be uniformly distributed within the zone. The water table at the retention basin site is approximately 50 feet below the surface (Ni94), therefore, the distance from the bottom of the contaminated zone to the water table is about 10.5 meters. A schematic of the basin, the excavated area, and the contaminated zone dimensions is presented in Figure 2. 
Figure 3 shows the dimensions of the covered contamination at the Old F-Area Retention Basin site assumed to exist as of January 1979. On visual inspection of the site, it is apparent that an additional mound of soil was added as a cover to the Basin. Documention on the physical dimensions of this additional cover is not available, therefore, the mounded soil dimensions are not included in the analysis. The diagram in Figure 3 is the representation utilized for the current study.

The contaminated area is located entirely in the vadose zone with a thick layer of unsaturated, clean soil separating it from the water table aquifer. All soils in both the unsaturated and saturated zones have a sandy loam texture with a bulk density of about $1.6 \mathrm{~g} / \mathrm{cm}^{3}$ (Lo87), an effective porosity of 0.45 (Ha94), and a total porosity of 0.2 (Lo87). Erosion of top soil occurs at a very slow rate of approximately $0.009 \mathrm{~cm} / \mathrm{yr}$ (Ro94).

Because of previous remediation attempts, it is assumed that the radioactivity in the contaminated zone was placed at the Old Retention Basin site in early 1979. For purposes of estimating future exposures only to Basin contamination, it is also assumed that the groundwater beneath the basin is currently free o: contamination. Pathways involving exposure to groundwater and/or surface water contamination begin with no contribution to dose and increase over time as the contaminant moves through the soil and as the cover soil is eroded. The height of the water table is assumed to change negligibly during the assessment period.

RESRAD contains two groundwater transport models, either of which can be invoked. For this analysis the code has been configured to use a nondispersion model when calculating groundwater transport of radionuclides. This type of model assumes that the dispersion of nuclides is negligible, the unsaturated and saturated zones are homogenous, and that water withdrawn from the down-gradient well introduces only minor perturbations in groundwater flow. This model is different from the alternative, a mass balance model, which assumes that all of the radionuclides released from the contaminated zone are withdrawn through a well located at the center of the contaminated zone. The mass balance model is inappropriate for use with large $\left(>1000 \mathrm{~m}^{2}\right)$ contaminated areas since all of the contamination is assumed to be retrieved through one well. 


\section{PARAMETER VALUE ASSIGNMENTS}

Parameter values and references are presented in Tables 1 and 2 for all user inputs to RESRAD. Several parameter values not normally adjusted by the user have been modified so that the transport and exposure models of RESRAD reflect values specific to the Savannah River Site (see Tables 3 and 4). For example, the parameter value describing nuclide resuspension (mass loading) is based on atmospheric and soil concentrations of plutonium at locations on the SRS. Additionally, because of the extensive studies of cesium accumulation in fish conducted at this site, a site-specific bioconcentration factor for cesium is included in the RESRAD library. The remaining bioaccumulation factors and stable element transfer coefficients for soil, meat, and milk also have been modified to be consistent with dosimetry codes utilized for SRS dose analyses.

\section{EXPOSURE SCENARIO}

The critical population for the determination of soil concentration guidelines is the future resident farmer (Gi89). Therefore, only the exposure scenario which is expected to result in the most conservative soil guidelines is considered. This scenario revolves around a family that is assumed to move onto the site after it has been released for use without radiological restrictions.

The contaminated land is assumed to be inhabited by a resident farmer at some point in the future. One-hundred percent of the future resident's drinking water if obtained from an onsite well located at the down-gradient edge of the contaminated zone. A pond, located adjacent to the contaminated zone and in the direction of the ground flow, is utilized for $100 \%$ of the farmer's fish consumption. The resident farmer grows vegetables, meat, and milk on the contaminated site and consumes amounts of these foods proportional to the contaminated area available for production, as long as the consumption rates do not exceed those specified in Table 2. The farmer is also assumed to remain indoors $50 \%$ of the time, outdoors $25 \%$ of the time, and away from the area $25 \%$ of the time (Gi89).

Overhead irrigation of food crops occurs at a rate equal to the average irrigation rate for the State of South Carolina (30 inches/yr). Also in accordance with South Carolina 
statistics, $56 \%$ of livestock water and $27 \%$ of irrigation water is obtained from groundwater supplies, the balance is obtained from an adjacent, uncontaminated pond (Lo83).

Table 1. Soil characterization parameter values for executing RESRAD.

\begin{tabular}{|c|c|c|c|}
\hline Parameter & Value & Units & Reference \\
\hline Cover depth & 2.7 & $\mathrm{~m}$ & $\operatorname{Sc} 87$ \\
\hline Contaminated area & 2250 & $\mathrm{~m}^{2}$ & Sc87 \\
\hline Contamination zone thickness & 2 & $\mathbf{m}$ & Sc87 \\
\hline Contamination length parallel to aquifer flow & 61 & $\mathbf{m}$ & $\operatorname{Sc} 87$ \\
\hline Unsaturated thickness below contamination & 10.5 & m & Sc87 \\
\hline Hydraulic gradient & 0.007 & - & Ge92 \\
\hline Well pump intake depth below water table & 10 & m & $*$ \\
\hline Watershed area for nearby stream or pond & $1,000,000$ & $\mathbf{m}^{2}$ & $\dagger$ \\
\hline Elapsed time of waste placement & 14 & yr & Sc87 \\
\hline Radiation dose limit & 4 & $\mathrm{mrem} / \mathrm{yr}$ & EPA DWS \\
\hline Precipitation rate & 1.2 & $\mathrm{~m} / \mathrm{yr}$ & Hu90 \\
\hline Irrigation rate & 0.76 & $\mathrm{~m} / \mathrm{yr}$ & Lo83 \\
\hline Well pumping rate & 250 & $\mathrm{~m}^{3} / \mathrm{yr}$ & $*$ \\
\hline Water table drop rate & 0 & $\mathrm{~m} / \mathrm{yr}$ & Ha94 \\
\hline Soil density & 1.6 & $\mathrm{~g} / \mathrm{cm}^{3}$ & Lo87 \\
\hline Erosion rate & 0.0009 & $\mathrm{~m} / \mathrm{yr}$ & Ro94 \\
\hline Total porosity & 0.45 & - & Ha94 \\
\hline Effective porosity & 0.2 & - & Lo87 \\
\hline Hydraulic conductivity & 378 & $\mathrm{~m} / \mathrm{yr}$ & Ge92 \\
\hline b parameter (Table E. 2 of reference) & 4.5 & - & Gi89 \\
\hline Evapotranspiration coefficient & 0.42 & - & Hu87 \\
\hline Runoff coefficient & 0.025 & - & Hu87 \\
\hline
\end{tabular}

"default value; ${ }^{\dagger}$ estimated with SRS topographical chart. 
Table 2. Radiation exposure parameter values for executing RESRAD.

Parameter

Value

Units

Reference

\section{Exposure Factors}

Inhalation rate

Mass loading

Dilution length for airborne dust

Exposure duration

Inhalation shielding factor

External gamma shielding factor

Indoor time fraction

$\begin{array}{ccc}8000 & \mathrm{~m}^{3} / \mathrm{yr} & \mathrm{NRC77} \\ 0.0002 & \mathrm{~g} / \mathrm{m}^{3} & \mathrm{Gi} 89, \mathrm{Cu} 91 \\ 3 & \mathrm{~m} & \mathrm{Gi} 89\end{array}$

$30 \quad y r$

OERR91

Outdoor time fraction

Vegetable consumption rate

0.4

Gi89

0.7

Gi89

0.5

Gi89

0.25

276

Leafy veg. consumption rate

43

230

81

19

35

730

36

52

70

110

0.5

0.15

Depth of soil mixing layer

Maximum root depth

1

0.56

Gi89

Fraction of livestock water from ground

0.27

$\mathrm{Ha} 92$

$\mathrm{Ha92}$

$\mathrm{Ha} 92$

Ha92

Ha92

OERR91

NRC77

$\mathrm{Ha} 92$

$\mathrm{Ha} 92$

Ma93

Fraction of irrigation water from ground

Gi89

Gi89, Pe83

Pe83

Lo83

Lo83 
Table 3. Contamination leach rates (Lo87) and bioaccumulation in freshwater fish (NRC77).

\begin{tabular}{lcc}
\hline Element & $\begin{array}{c}\text { Leach Rate } \\
(1 / \mathrm{yr})\end{array}$ & $\begin{array}{c}\text { Bioaccumulation } \\
(\mathrm{L} / \mathrm{kg})\end{array}$ \\
& & \\
Cesium & $4.74 \times 10^{-4}$ & 3000 \\
Lead & $2.37 \times 10^{-3}$ & 100 \\
Plutonium & $2.37 \times 10^{-3}$ & 3.5 \\
Radium & $2.37 \times 10^{-3}$ & 50 \\
Strontium & $2.94 \times 10^{-2}$ & 30 \\
Thorium & $2.37 \times 10^{-3}$ & 30 \\
Uranium & $5.95 \times 10^{-3}$ & 2 \\
\hline
\end{tabular}

Table 4. Stable element transfer coefficients for plant, meat, and milk uptake (NRC77).

\begin{tabular}{llll}
\hline Element & Plant & Meat (d/kg) & Milk (d/kg) \\
& & & \\
Cesium & 0.04 & 0.03 & 0.008 \\
Lead & 0.01 & 0.0004 & 0.0003 \\
Plutonium & 0.001 & 0.0001 & 0.000001 \\
Radium & 0.04 & 0.001 & 0.001 \\
Strontium & 0.3 & 0.008 & 0.002 \\
Thorium & 0.001 & 0.0001 & 0.000005 \\
Uranium & 0.0025 & 0.00034 & 0.0006 \\
\hline
\end{tabular}




\section{RESULTS}

Soil guidelines for Sr-90, Cs-137, and Pu-238 at the Old F-Area Retention Basin site are given in Table 5. Also listed in the table are nuclide half-lives and the time over the next 1000 years at which the minimum soil guideline occurs (i.e., time at which the dose limit is reached). Plots of soil guidelines as a function of time for each nuclide are given in Figures 4 through 6 . The lowest point on these plots is the limiting value that determines the concentration guideline.

Soil guidelines are developed under the assumption that only one radionuclide is contaminating the soil. When multiple radionuclides are present, guidelines may have to be reduced so that the total dose from all nuclides does not exceed the basic dose limit. Since, in this case, the dose from each nuclide is delivered at different times, the reductions are negligible in the scenario presented.

Water consumption dominates the guideline for strontium with only secondary contributions to dose from plant consumption. Strontium is faster moving through soil than are cesium and plutonium causing it to appear in the groundwater sooner. The cesium soil guideline is dominated by the external radiation exposure pathway. This pathway becomes important as the contamination becomes exposed through surface erosion. The pathways of inhalation and plant ingestion dominate the guideline for plutonium. Plant contamination occurs due to uptake by plants rooting in the contaminated soil.

Generally, the external gamma exposure, food consumption, and inhalation pathways dominate in the earlier years with the groundwater and surface water pathways increasing in significance once nuclides begin to migrate from the contaminated zone into the saturated zone. Some nuclides have such short half-lives that they decay before reaching the groundwater. Others, however, have very long half-lives and result in greater exposures once reaching the water dependent pathways.

Uncertainties obviously exist in the soil guidelines, primarily because of uncertainties in the parameters used to describe soil characteristics. Groundwater transport modeling uncertainties range from nil, because groundwater movement is not significant to 
exposure by a particular nuclide, to very high, depending on groundwater modeling assumptions.

Table 5. RESRAD soil guidelines for the Old F-Area Retention Basin site based on a dose limit of $4 \mathrm{mrem} / \mathrm{yr}$.

$\begin{array}{cccc} & & \text { RESRAD } & \text { Time of } \\ \text { Nuclide } & \text { Half-life } & \text { Soil Guideline } & \text { Maximum } \\ & (\mathrm{yr}) & (\mathrm{pCi} / \mathrm{g}) & \text { Dose }(\mathrm{yr})\end{array}$

$\begin{array}{lccc}\text { Sr-90 } & 28.6 & 10 & 90 \\ \text { Cs-137 } & 30.2 & \dagger & - \\ \text { Pu-238 } & 87.7 & 7200 & 770\end{array}$

$†_{\text {at specific activity level. }}$

\section{SOIL GUIDELINES BASED ON AREA OF CONTAMINATION}

To provide additional information on the relationship between the size of the contaminated area and the concentration guideline, guidelines were calculated as a function of contaminated area. This information is useful in determining remediation alternatives related to the volume of soil to be removed to achieve groundwater concentrations below the drinking water standard.

The RESRAD code models a drinking-water well at the down gradient edge of the contaminated area. As the area of contamination increases, the concentration guideline decreases meaning that lower soil concentrations result in the same dose standard (4 mrem/yr in this case).

Figures 7 and 8 show soil guidelines as a function of contaminated area for $\mathrm{Sr}-90$ and $\mathrm{Pu}$ 238. Since cesium is immobile, its soil guideline is equal to its specific activity. The curves in Figs. 7 and 8 show the same characteristics of a linear decrease (on a log-log scale) to a point where the soil concentration reaches a constant minimum value. An explanation of this characteristic is given below with reference to Figure 9. 
Since the drinking-water well is modeled at a finite depth (10 meters) and at the downgradient edge of the contaminated area, a critical area is reached (by increasing L in Fig. 9) where all water entering the well is contaminated. The length $\mathrm{L}$, where this occurs relates to the point at which the function in Figs. 7 and 8 becomes constant, is determined by the infiltration rate (contaminated inflow) and the groundwater flow rate (uncontaminated inflow).

\section{HOT-SPOT CONTAMINATION GUIDELINES}

The guidelines given in Table 5 represent the average soil concentration in the contaminated zone beneath the Old Retention Basin that would eventually result in dose estimates of approximately $4 \mathrm{mrem} / \mathrm{yr}$ via all potential exposure pathways. Due to the physical location of the contaminated soil, however, exposures occur only through the groundwater pathway. Given that the contamination is generally uniformly distributed and the average concentration of a particular nuclide is less than the concentration guideline, the dose limit of 4 mreri/yr via groundwater will not be exceeded. Localized areas of high concentration (hot-spots), however, may result in larger than expected exposures.

The probability that hot-spots exist in the soil below the old F-Area retention basin is very small. Since the basin received contamination in an aqueous form it is unlikely that any one area within the basin was significantly more contaminated than any other area. However, hot-spot guidelines for the basin have been estimated for the sake of conservatism.

Exposures to the resident farmer from a single hot-spot have been modeled in the following manner: 1) the volume of the hot-spot is assumed to be $1 \mathrm{~m} \times 1 \mathrm{~m} \times 1 \mathrm{~m}, 2$ ) the hot-spot is at the deepest location in the contaminated zone (nearest the water table), and 3) all contamination leaving the hot-spot is assumed to be drawn to the surface through the drinking-water well. All other parameters are equivalent to those used to estimate the residual soil guidelines of Table 5 .

Using RESRAD, it is estimated the hot-spot guideline for Cs-137 is at its specific activity limit, i.e., the amount of contamination could be at its maximum possible concentration and the dose limit still would not be exceeded. The hot-spot guidelines for Sr-90 and Pu- 
238 are $4500 \mathrm{pCi} / \mathrm{g}$ and $1100 \mathrm{pCi} / \mathrm{g}$, respectively. These values, along with the concentration guidelines given in Table 5, can be interpreted to mean that, as along as the average soil concentration is less than the soil guideline and the maximum concentration is less than the hot-spot guideline, the dose to the maximally exposed individual will not exceed the basic dose limit of $4 \mathrm{mrem} / \mathrm{yr}$ via consumption of groundwater.

\section{REFERENCES}

(Cu91) Cummins, C.L.; Martin, D.K.; Todd, J.L. Savannah River Site enviromental report for 1990. Westinghouse Savannah River Company. Aiken, SC: Report No. WSRC-IM-91-28; 1991.

(Ge92) Geotrans. Groundwater flow model for the general separations area, Savannah River Site. GeoTrans, Inc. Aiken, SC: Project No. 3017-003; 1992.

(Gi89) Gilbert, T.L.; Yu, C.; Yuan, Y.C.; Zielen, A.J.; Jusko, M.J.; Wallo, A. A manual for implementing residual radioactive material guidelines. Argonne National Laboratory. Argonne, IL: Report No. ANL/ES-160; 1989, 1-203.

(Ha92) Hamby, D.M. Site-specific parameter values for the Nuclear Regulatory Commissions food pathway dose model. Health Physics. 62:136-143; 1992.

(Ha93) Hamby, D.M. Soil concentration guidelines for the Savannah River Site using the DOE/RESRAD methodology. Westinghouse Savannah River Company. Aiken, SC: Report No. WSRC-TR-93-304; 1993.

(Ha94) Haselow, J.S. Westinghouse Savannah River Company. personal communcation. January 4, 1994.

(Hu87) Hubbard, J.E.; Englehardt, M. Calculation of groundwater recharge at the old SRP burial ground using the CREAMS model (1961-1986). E.I. duPont de Nemours \& Company. Aiken, SC: Report No. DPMS-87-126; 1987, 111. 
(Hu90) Hunter, C.H. A climatological description of the Savannah River Site. Westinghouse Savannah River Comany. Aiken, SC: Report No. WSRC-RP89-313; 1990.

(ICRP91) International Commission on Radiological Protection. Risks associated with ionising radiations. Pergamon Press. New York, NY: Vol. 22, No. 1; 1991.

(Lo83) Lonon, G.E.; Burnette, C.B.; Morris, H.J. Water use in South Carolina, 1980. South Carolina Water Resources Commission. Columbia, SC: Report No. $138 ; 1983$.

(L087) Looney, B.B.; Grant, M.W.; King. C.M. Estimation of geochemical parameters for assessing subsurface transpnrt at the Savannah River Plant. E.I. duPont de Nemours \& Company. Aiken, SC: Report No. DPST-85-904; 1987.

(Ma93) Mathis, T. Aiken County Extension Service. personal communication. March 10, 1993.

(Ni94) Nix, D.W. Depth to water table at old F-Area retention basin. personal communication. January 18, 1994.

(OERR91) Office of Emergency and Remedial Response. Standard default exposure factors. Supplemental Guidance. Washington, DC: Report No. OSWER 9285.6-03; 1991.

(Pe83) Peterson, H.T. Terrestrial and aquatic food chain pathways. In: Radiological Assessment. (J.E. Till; H.R. Meyer, eds.). Nuclear Regulatory Commission. Washington, DC: Report No. NUREG/CR-3332; 1983.

(Ro94) Rogers, V.A. Erosion factor for waste site cap. Westinghouse Savannah River Company. Aiken, SC: Report No. SRT-ESS-94-113. 1994. 
(Sc87) Scott, S.C.; Killian, T.H.; Kolb, N.L.; Corbo, P.; Marine, I.W. Separations area retention basins. E.I. duPont de Nemours \& Company. Aiken, SC: Report No. DPST-85-693; 1987.

(EPA91) U.S. Environmental Protection Agency. Risk assessment guidance for Superfund: Volume 1 - Human health evaluation manual (Part B, Development of risk-based preliminary remediation goals). Office of Emergency and Remedial Response. Wäshinington, DC: Report No. 9285.701B; 1991.

(NRC77) U.S. Nuclear Regulatory Commission. Calculation of annual doses to man from routine releases of reactor effluents for the purpose of evaluating compliance with 10 CFR Part 50, Appendix I. Washington, DC: Regulatory Guide 1.109, Rev. 1; 1977. 
Figure 1

RESRAD Schematic

of the Nondispersion Model

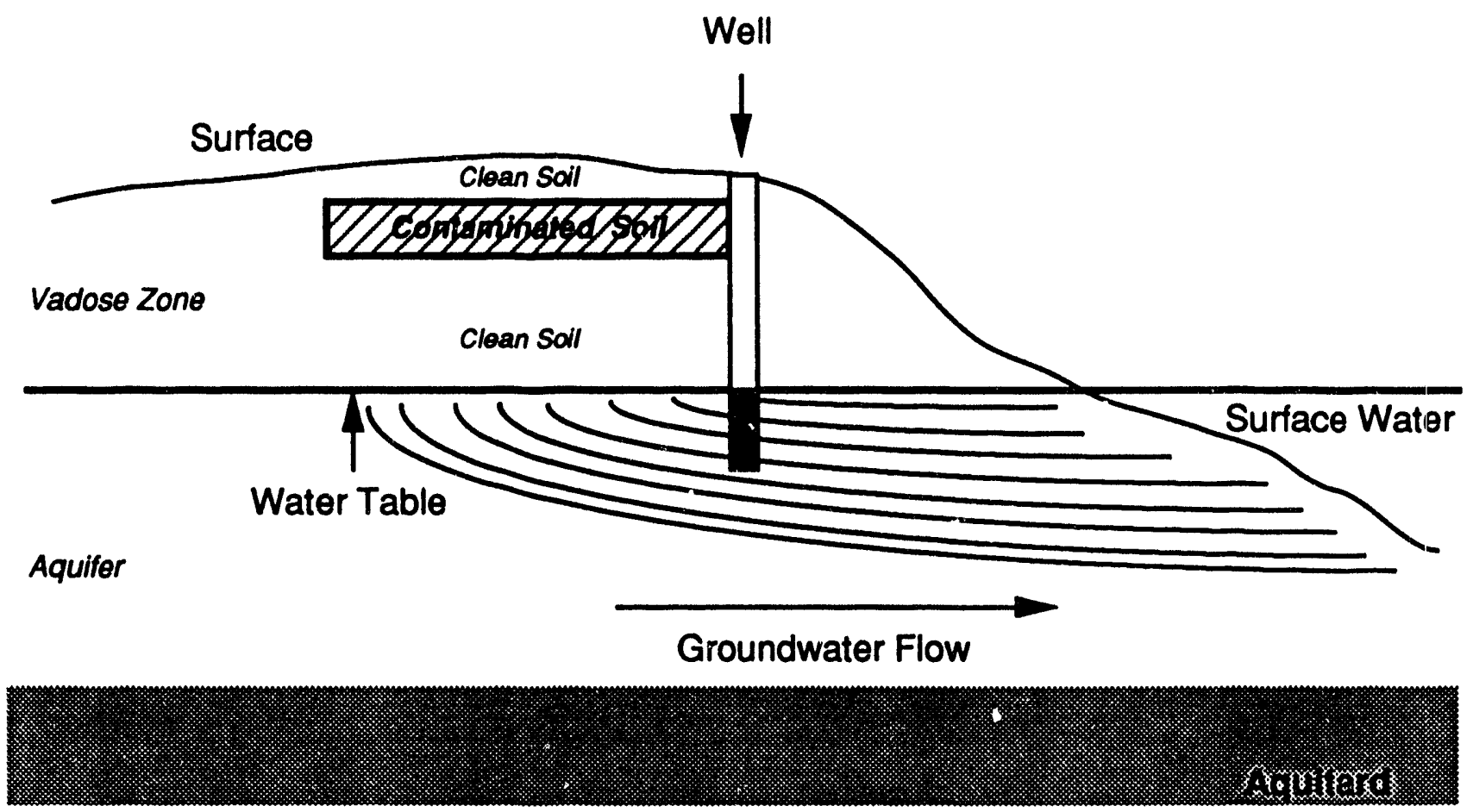


Figure 2

\section{RESRAD Conceptual Modiel}

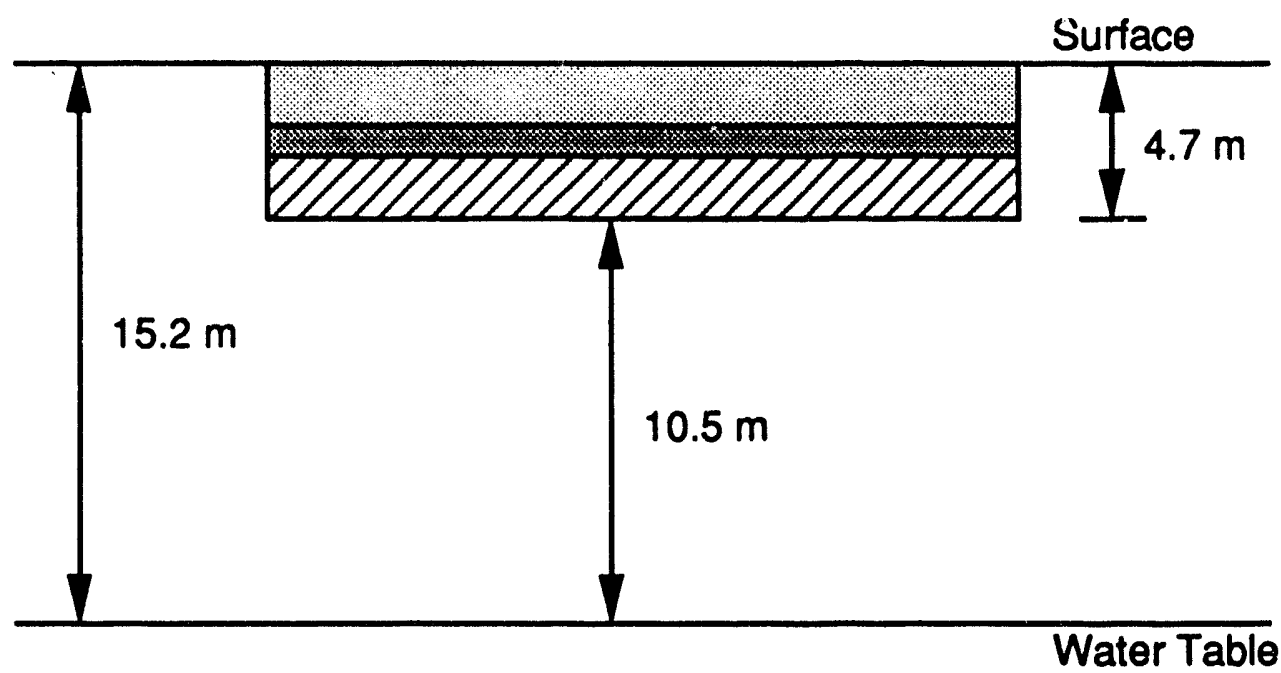

Original basin depth $(2.1 \mathrm{~m})$

Excavated soil $(0.6 \mathrm{~m})$

D Contaminated zone $(2 \mathrm{~m})$ 
Figure 3

F-Area Retention Basin Contamination with Cover

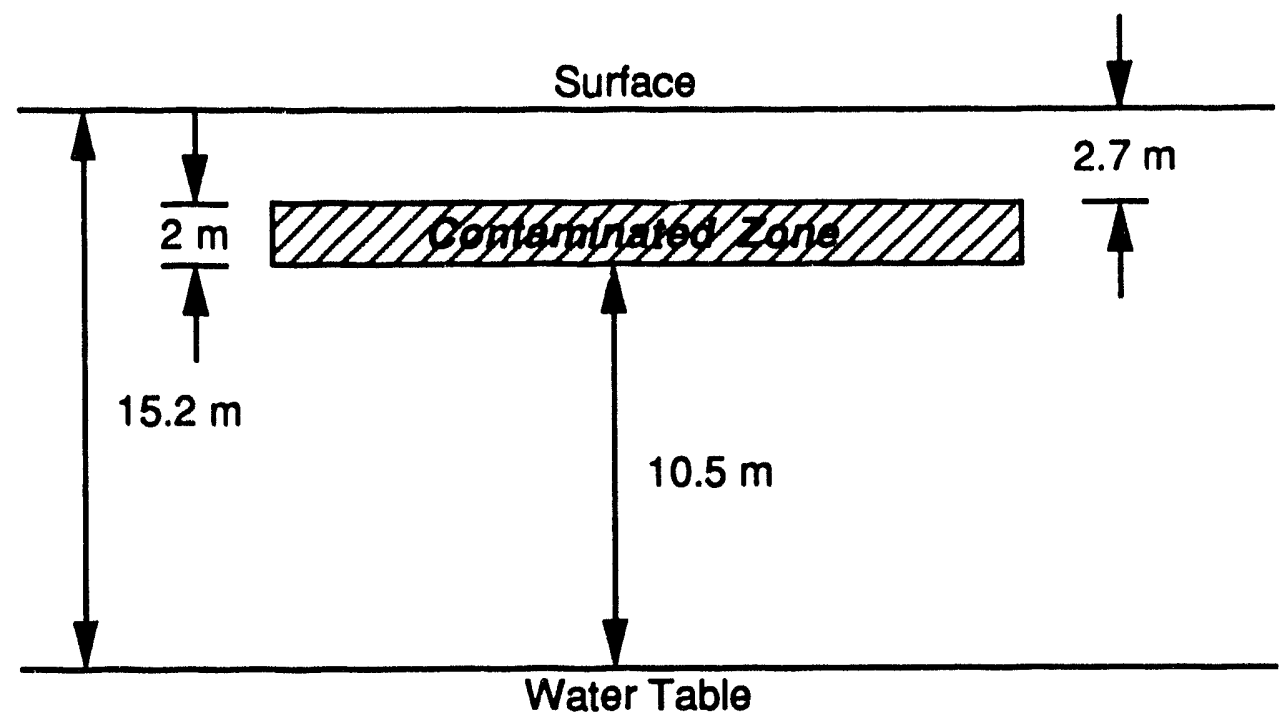




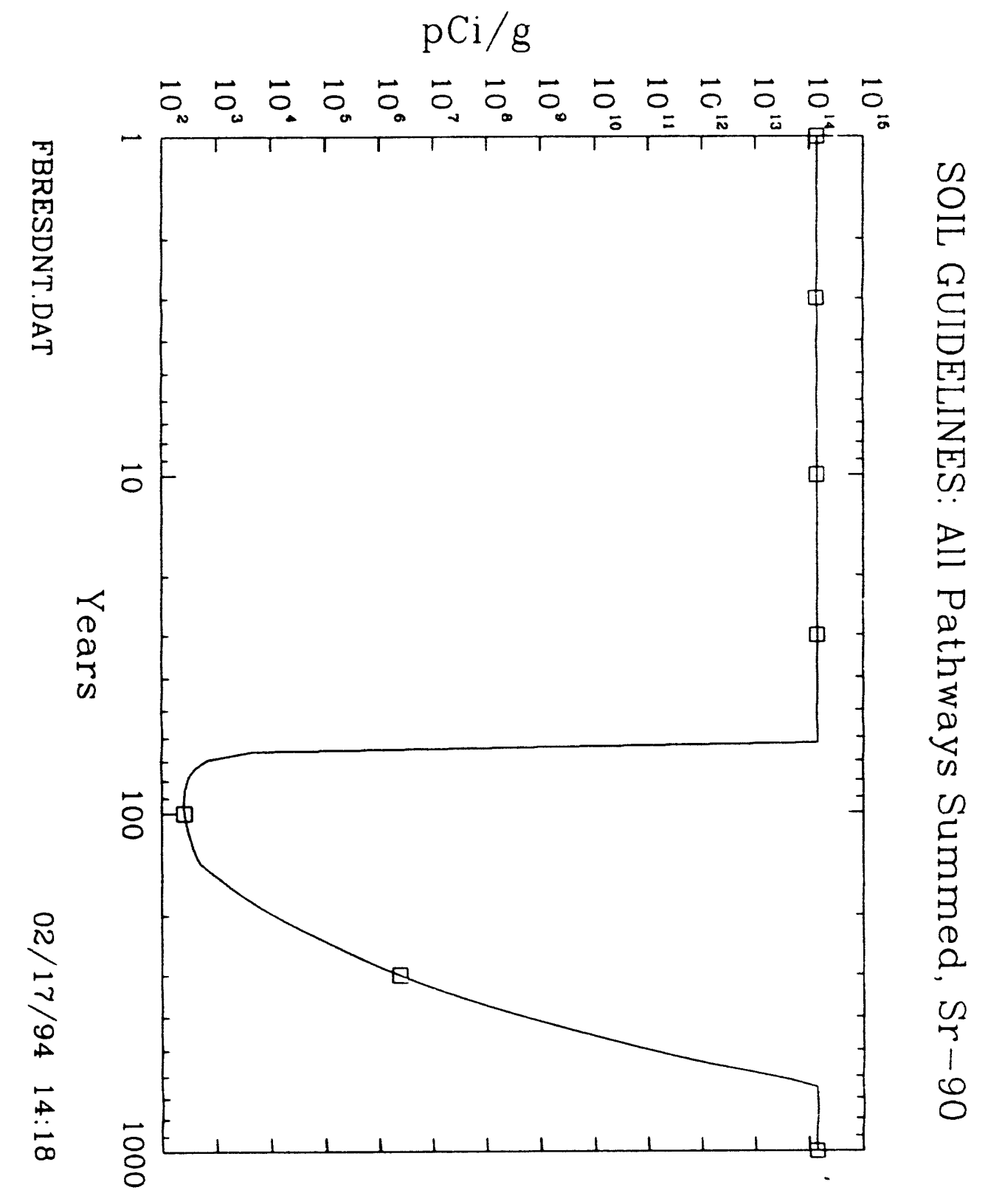

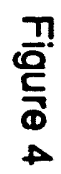


Figure 5

SOIL GUIDELINES: All Pathways Summed, Cs-137

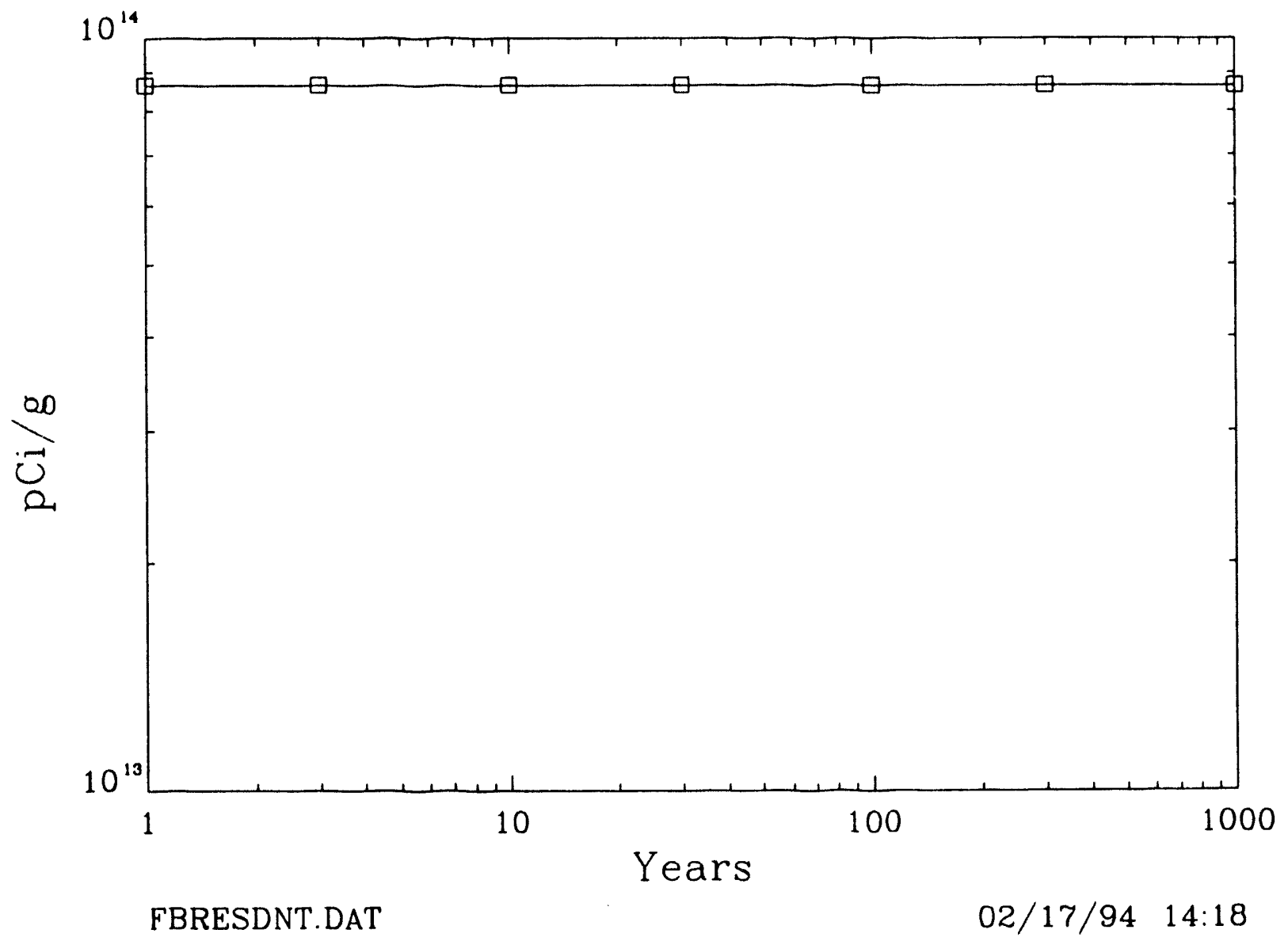


Figure 6

SOIL GUIDELINES: All Pathways Summed, Pu-2.38

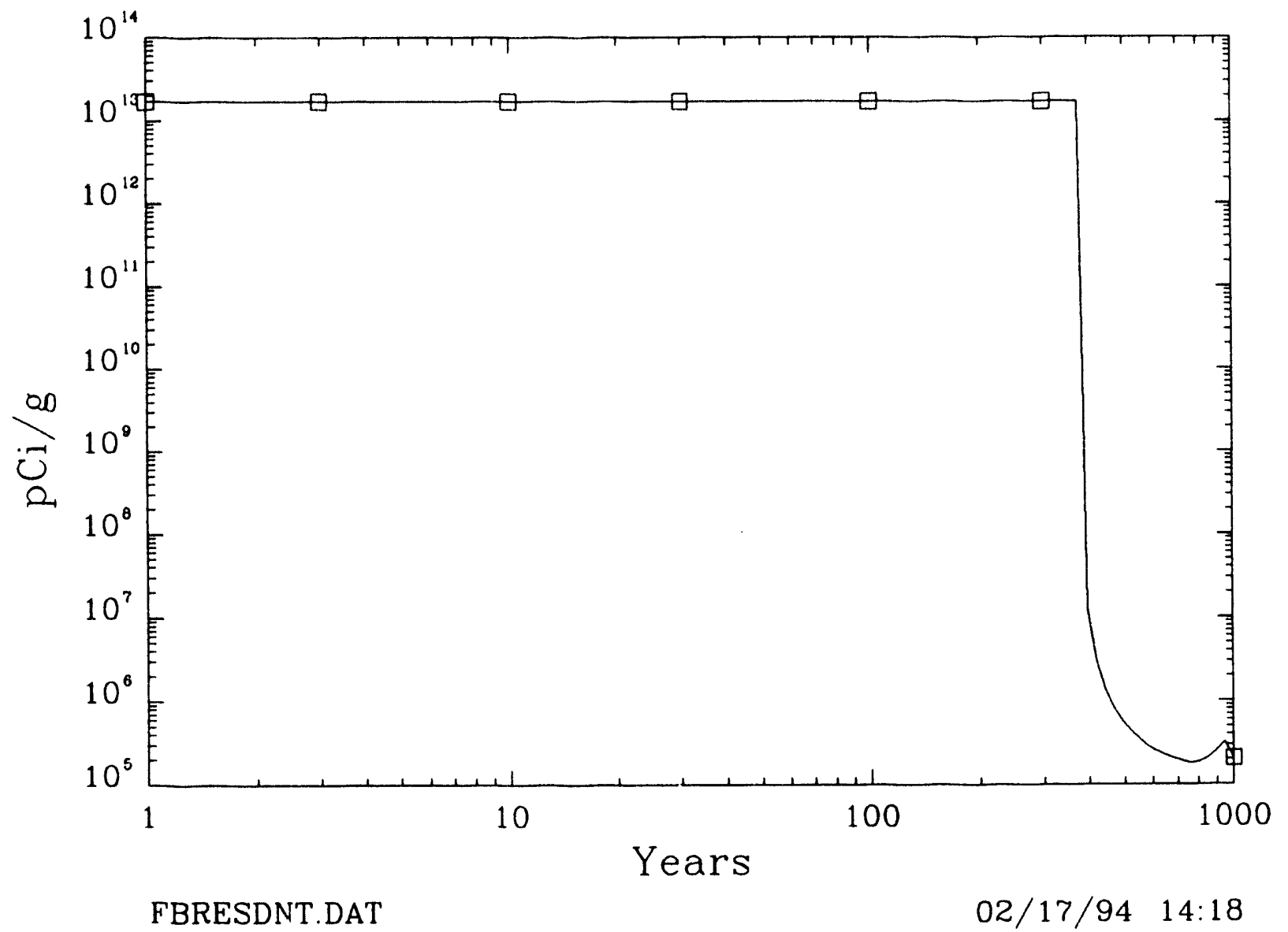


Figure 7. Soil Guideline for Sr-90 as a function of Contaminated Area

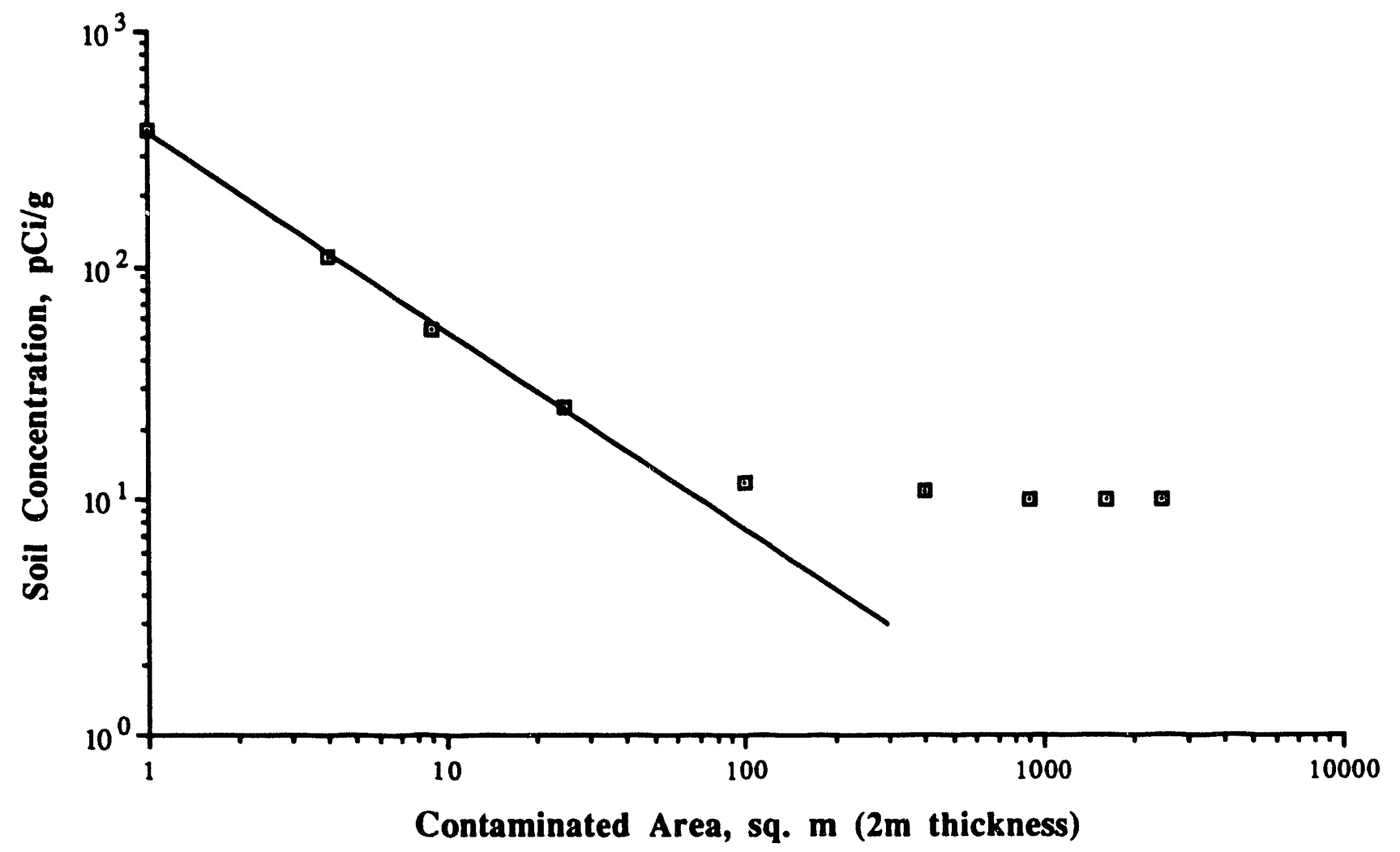


Figure 8. Soil Guideline for Pu-238 as a function of Contaminated Area

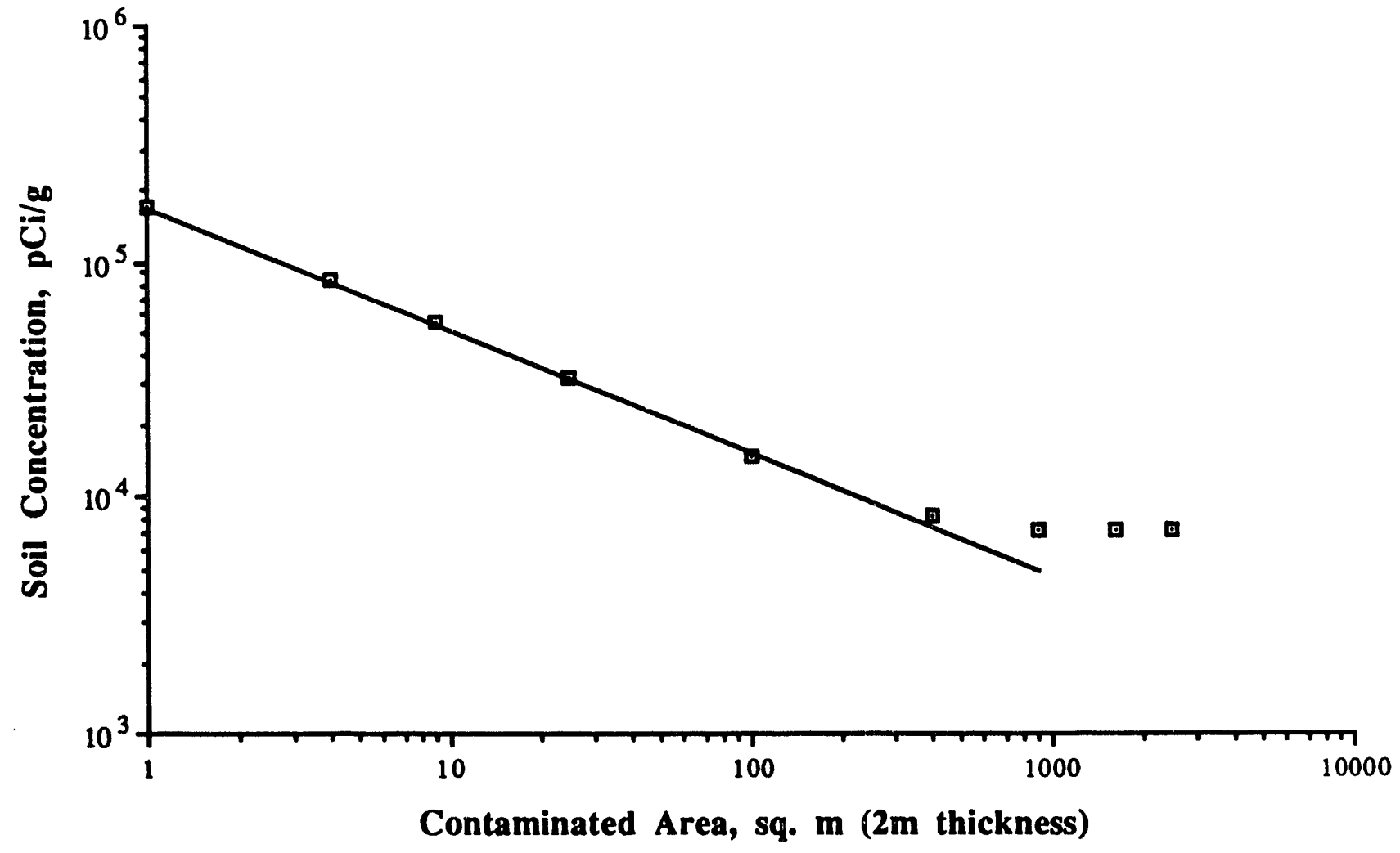


Figure 9

Schematic of Water Inflow to the Drinking-Water Well

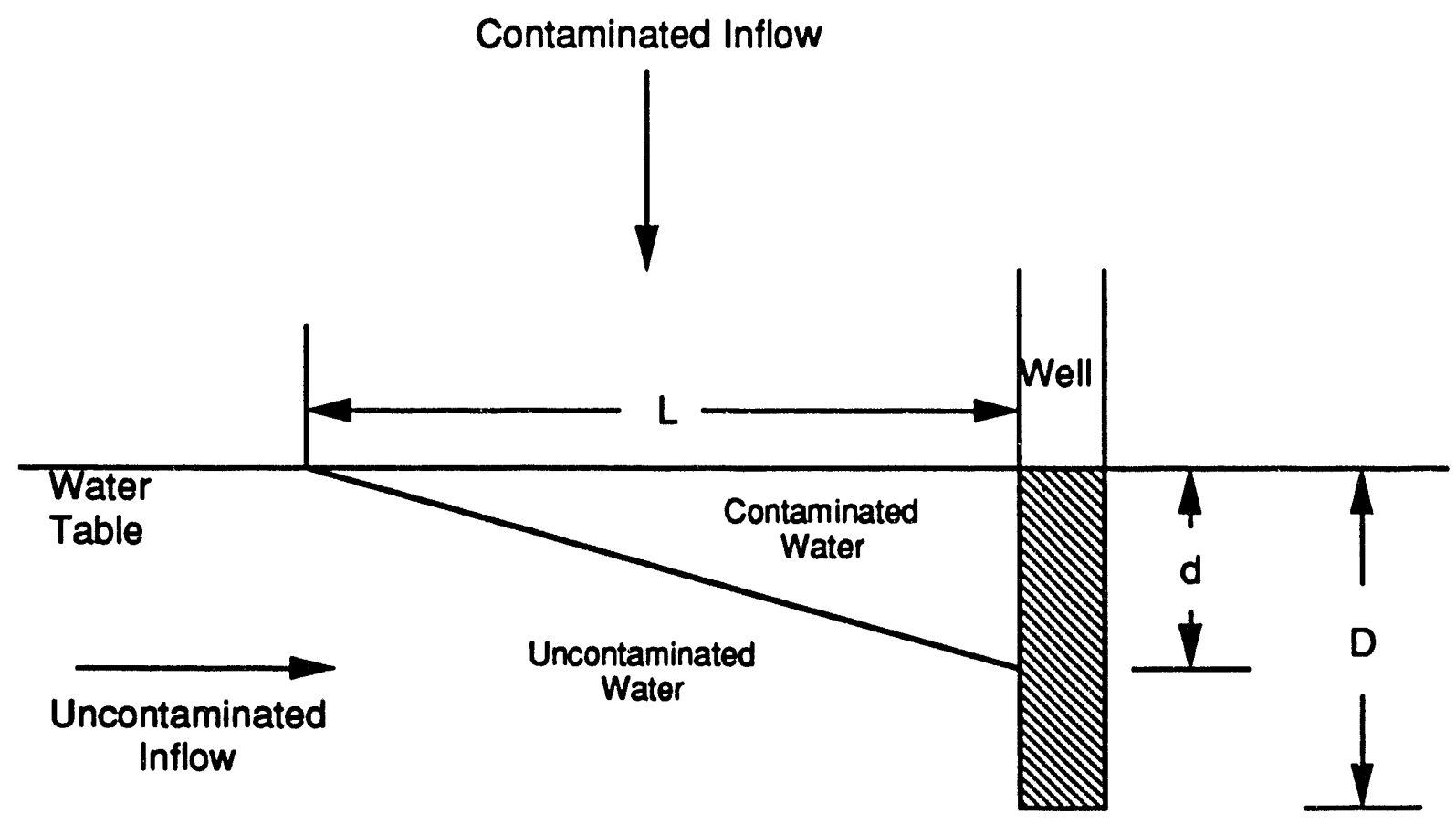

$L=$ length of contaminated area parallel to groundwater flow

Dilution Factor $=\frac{d}{D}$ 

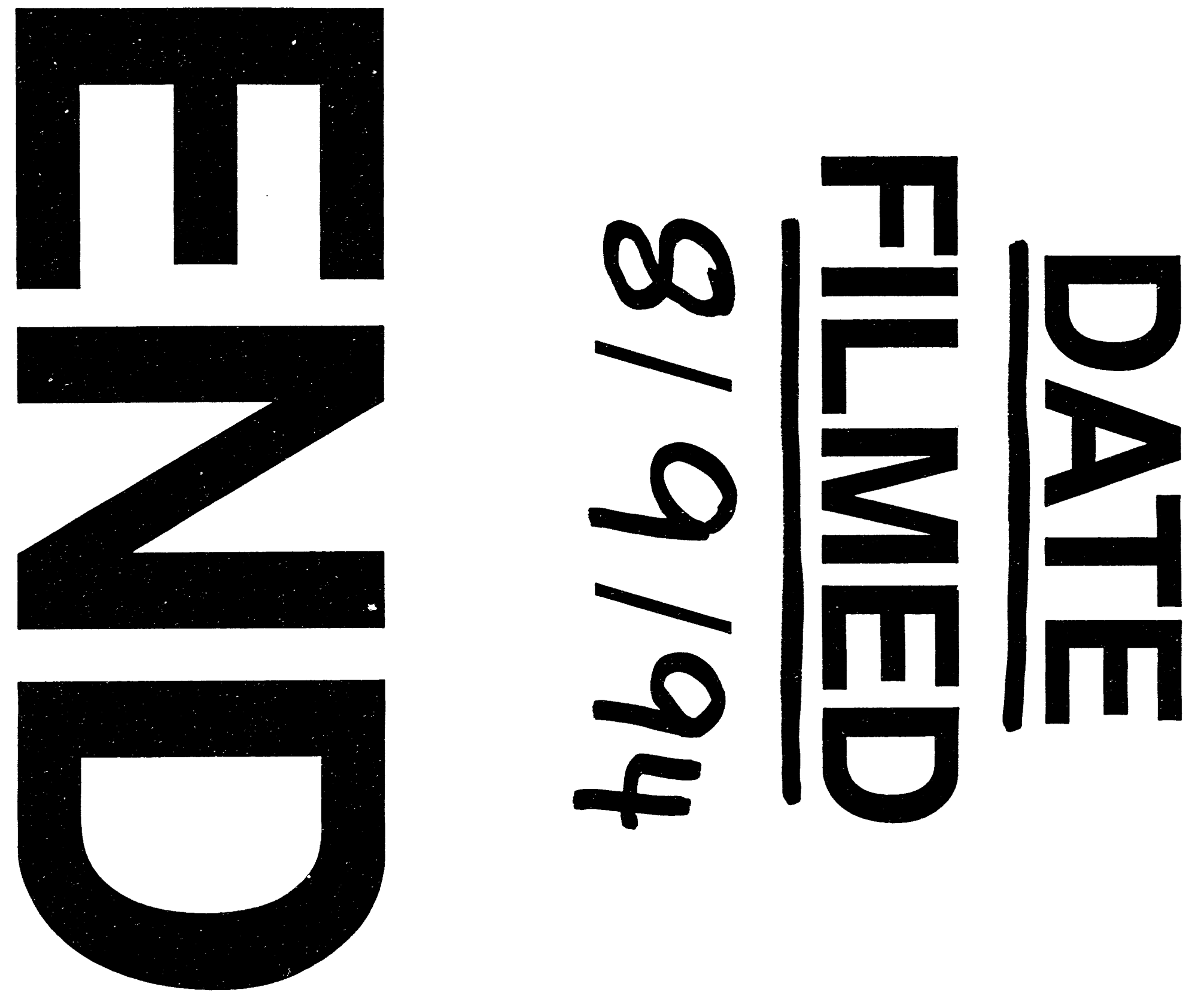
